\title{
Interpretation of Space and Political Dynamics of Rohingya-Spatial and International Relations Approaches
}

\author{
Aysha Rizki Ramadhyas ${ }^{1}$, Muhamad Iko Kersapati², Hagi Mulya \\ Sandhika $^{3}$, Diah Desita Damayanti ${ }^{4}$ \\ \{aysha.rizki@ui.ac.id ${ }^{1}$,muhamad.iko@sci.ui.ac.id², hagi.mulya@gmail.com ${ }^{3}$, \\ diah.desita91@ui.ac.id $\left.{ }^{4}\right\}$ \\ Terrorism Studies-Universitas Indonesia ${ }^{1}$, Department of Geography- \\ Universitas Indonesia ${ }^{2}$, Department of International Relations- Pelita \\ Harapan University ${ }^{3}$, Department of Geography-Universitas Indonesia ${ }^{4}$
}

\begin{abstract}
This study discusses about Rohingya ethnical conflict as political phenomena. The data used in this study were qualitative from various literature: international news, scientific journals, and maps. The method used in this research was interpretation, and Geographic Information System (GIS) as a tool to reveal the spatial and political dynamics of the conflict. There were six maps produced as the basis of explanation. The results showed that the democratic transition as the turning point of democracy in Myanmar gave an effect on the economic activity and implication to the ethnical claim of territories. The democratic transition period that occurred in Myanmar provided an opportunity for foreign economic power such as China to build the oil and gas pipeline. This condition led to land grabbing and marginalization of Rohingya as the inhabitant. Meanwhile, in political responses, Indonesia and Malaysia gave pro response, while Bangladesh and Thailand were still in pro and contra responses.
\end{abstract}

Keywords: Ethnical Conflict, Geographic Information System (GIS), International Politics, Political Mapping.

\section{Introduction}

Human rights are the fundamental right to all human beings without regard to their nationality, religion, sex, language, and color. Human rights consist of several reasons such as the right to life, the rights to development and self-determination, rights to work, and education. All countries in this world may have to treat humans equally without any discrimination. For example, in the United States of America, in terms of protecting human rights in 1941, Franklin D. Roosevelt proposed four freedoms guaranteed by the U.S Constitution; freedom of religion, speech, expression, God worshiping, desire, and fear. Therefore, The Universal Declaration of Human Rights in 1948 and The Vienna World Conference on Human Rights promoted and protected human rights as a fundamental freedom of individuals or groups.

Nevertheless, there were human rights violation issue that happened in 2017. State violence against Muslim minority in Rakhine State, Myanmar became the most significant world attention for months after an astounding attack from Rohingya insurgents to Myanmar army post on August, 25th 2017 [1]. Unfairly, the oppressive Military Junta has abused, treated even killed hundreds of people. Rohingya did not correctly get their rights to live; the 
conflict destroyed their living areas as the international community said it was an example of an ethnic cleansing that recently happened in Myanmar. Furthermore, 450,000 of Rohingya have fled to Bangladesh, which was geographically close to their homeland to escape and seeking for a camp and humanitarian aid [2].

This humanitarian issue has successfully attracted many responses from several countries such as Indonesia and Bangladesh. Indonesian Foreign Affairs Minister, H.E. Retno L. P. Marsudi, revealed that her visit to Myanmar aimed to discuss several agenda with not only Myanmar's Minister-Counselor, Aung San Suu Kyi, but also Myanmar's military commander, Min Aung Hlaing [3]. Foreign Minister Indonesia conveyed Aung San Suu Kyi had to immediately restore its domestic stability by both reducing the use of violence in terms of resolving Rohingya in Rakhine State and granting protection for Rakhine's citizen without regard to their ethnicity as well as religion. Besides that, Myanmar had to urge its openness for humanitarian access to prevent humanitarian crisis that may lead to instability.

So, the consequences will potentially affect the living space, not only Myanmar but also the region of South East Asia. Mid and long-term cooperation in the field of foods, health, and education needed in terms of minimizing the risk of instability of the region [4]. On the 30th ASEAN Summit in Manila, Philippines, Retno L. P. Marsudi delivered Indonesia's support for solution to the Rohingya and its effort in transforming Myanmar to become "the freediscrimination region" [4]. From that, this study examines the political processes in the ethnical conflict of Rohingya, including ethnical claimed territories, the chronology of conflict, and responses of neighbor countries that can affect the stability of political relations, particularly in the ASEAN through spatial and international relations perspective.

\section{Methodologies and Approaches}

\subsection{Conceptual Framework}

The approach used in this study is a spatial and international relations approach to examine the racial politics in Myanmar and neighboring countries. In political science, investigation of racial politics can be traced by Key's seminal research and translated into geographical structure of racial behavior. Geography as an interdisciplinary science is a key for better understanding of political behavior. In social context, politics has regarded as a set of correlated social phenomena instead of individual actions specifically in geographical political systems [5]. The following figure shows the conceptual framework of the research. 


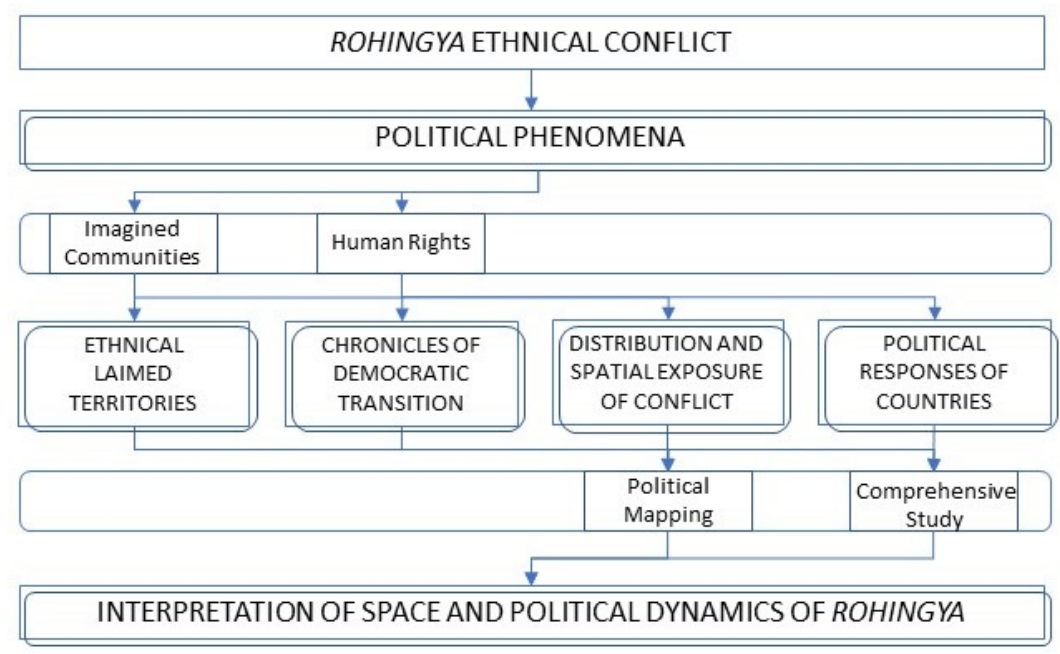

Fig. 1. Conceptual Framework of Research.

There are four major themes examined in this study: Ethnical Claimed Territories, Chronicles of Democratic Transition, Distribution and Spatial Exposure of Conflict, and Political Responses of Countries. The issues are analyzed in some countries: Myanmar as the center of conflict, Bangladesh, Thailand, Malaysia, and Indonesia as the neighboring countries. The method used in this study is qualitative method and data used in this study is qualitative data from various literatures: social science journals, international news, and maps.

\subsection{Theoretical Approaches}

\subsubsection{Imagined Communities as an Approach to Nationalism}

Nationalism was being a critical aspect of territorial conflicts and became the primary consideration of the political views. The word "imagined" from Anderson's in Imagined Communities has a deep meaning in elaborating the essence of a nation.

"It is imagined because the members of even smallest nation will never know most of their fellow-members, meet them, or even hear of them, yet in the minds of each lives the image of their communion" [6].

According to the statement, several significant points that could not be ruled out in the imagining process were mentioned in his book. Imagined Communities Reflected on The Origin and Spread of Nationalism covering cultural roots, angle of history, origins of nationwide understanding, pioneers of creole, ancient language, recent models, sense of nationalism and imperialism fighting, aspect of patriotism, racism, last wave, census, map, museum, memory, and forgetting.

The concept of nationalism brought awareness to the understanding of earth's surface, mainly the European, to fulfill their missions in gold, glory, and gospel. In purpose of 
imagining of Southeast Asians, the colonizers in beginning era fetched the picture of it. This map was known as Mercatorian map [6]. Anderson stated that if an author could write everything base on his/her perspective, so as a drawer could create a map as representative of the earth's surface.

They are Including only image of land (terrestrial) in odd oblique view because of differences of terrain or elevation and also the shape of earth which has to be projected in several types of projections both vertical and horizontal in cosmographical aspect [6].

Thongchai Winichakul, through his book Siam Mapped, stated that the guide maps are usually made locally with micro-scale situation and unstable geographic context, instead of universal convention of modern maps. His statement was supported by the formulation of Richard Muir stated that their makers would have found incomprehensible as the following:

"Located at the interfaces between adjacent state territories, international boundaries have a special significance in determining the limits of sovereign authority and defining the spatial form of the contained political region...Boundaries...occur where the vertical interfaces between state sovereignties intersect the surface of the earth. ...As vertical interfaces, boundaries have no horizontal extent..." [7].

In the link of geographical aspect, the period of the colonialization was bringing the exposure to the depiction of space, particularly to the colonized countries. Second half of 19th century was known well as the golden age of military surveyors. In that period, creating image of space was on the march of census makers in Southeast Asia [6]. As Thongchai stated:

"In terms of most communication theories and common sense, a map is a scientific abstraction of reality. A map merely represents something which already exists objectively 'there.' In the history I have described, this relationship was reversed. A map anticipated spatial reality, not vice versa. In other words, a map was a model for, rather than a model of, what it purported to represent. ... It had become a real instrument to concretize projections on the earth's surface. A map was now necessary for the new administrative mechanisms and for the troops to back up their claims. ... The discourse of mapping was the paradigm which both administrative and military operations worked within and served." [8].

\subsubsection{Concept of Human Rights}

Human rights are the fundamental concept to all human beings, which obligated to be protected by the rule of law. Human rights as constructed by United Nations on the United Nations Declaration of Human Rights 1948, show that every human was born in equal rights of men and women, and they have their freedom to set their standards of life as they wished to have. As stated by United Nations:

"Everyone is entitled to all the rights and freedoms set forth in this Declaration, without distinction of any kind, such as race, color, sex, language, religion, political or other opinion, national or social origin, property, birth or other status. Furthermore, no distinction shall be made on the basis of the political, jurisdictional or international status of the country or territory to which a person belongs, whether it be independent, trust, non-self-governing or under any other limitation of sovereignty." [9]. 
Montero (2014) has defined human rights in two categories, natural rights approach and political approach. The concept of human rights, according to the natural rights approach, explains how human rights entitle an individual to determine goods and services such as education, healthcare, etc. [10]. The natural rights approach allows people to enjoy four freedom of life (freedom of speech, freedom of fear, freedom of worship, freedom of want).

Therefore, every individual should promote and respect the value of human rights in life. Meanwhile, the political approach refers to the role of states in creating, developing, and implementing human rights in any sector of state regulations. States are obligated to protect their people from being tortured and not to abuse them. Montero explained the concept of human rights should be implemented at the level of state regulations, and sanctions must be applied for those offenders who against the law.

At the level of implementation, many obstacles have been found related to promote and protect human rights. Nishikawa (2018) showed a phenomenon on the lack of ASEAN's in dealing with the Rohingya crisis and protecting human rights. The concept of ASEAN way has not optimally been implemented since the principle of ASEAN Way (non-interference) becomes the barrier for ASEAN countries in dealing with Rohingya and on-going human rights violations [11]. Hence, the concept of human rights is used to urge the state's responsibility and the international community to deal with human rights violations in Myanmar.

As mentioned earlier, human rights-based on the natural rights approach stands for the explanation of why does the country should have considered the concept of human rights in terms of protecting human dignity philosophically. Besides that, human rights-based on political approach represent states' role in the implementation of the concept of human rights into state law and regulations, including applying the sanctions to all offenders based on the formed provisions.

\subsubsection{Geographic Information Systems in Political Studies}

Politics, as the phenomena of human activities on the earth leads to the spatial pattern and structure in imagined point, line, and area are expressed in a map. Mapping is essential in political study to reveal the explanation of the phenomena from a spatial perspective. Geographic Information System (GIS), as the best tool, shows the spatial relations based on theories and social context in a map. The capability of GIS in shaping image of georeferenced data into a map is the fundamental purpose. Furthermore, geographical analysis also increases the capability of GIS in measurement and investigation of spatial interaction and organization such as flow, distance, proximity, density, and shape in different scale [5].

The maps are not only used for in-depth analysis of, but also as tools of presentation. Regarding violence analysis, they are providing public information related to the domestic violence scope - places and intensity of occurring - and also providing information and education [12]. The identification process of the earth's surface was using satellite imagery, which indicated the hot spots on the exposed area. In advance analysis, this source of data could be the base in identifying the IDPs (Internally Displaced Persons) in particular grid units.

The next level of the question is, "How important the IDPs identification in the exposed area of the violence?" Almost all of the first-step restoration should be based on the maps and another spatial indicator, which can lead to the right decisions. The attempts include returning rights recovery and reconciliation between displaced people and communities such as 
reintegration and restoration in legal, political order re-establishment, economic infrastructure, institution, and sustainable capability [13].

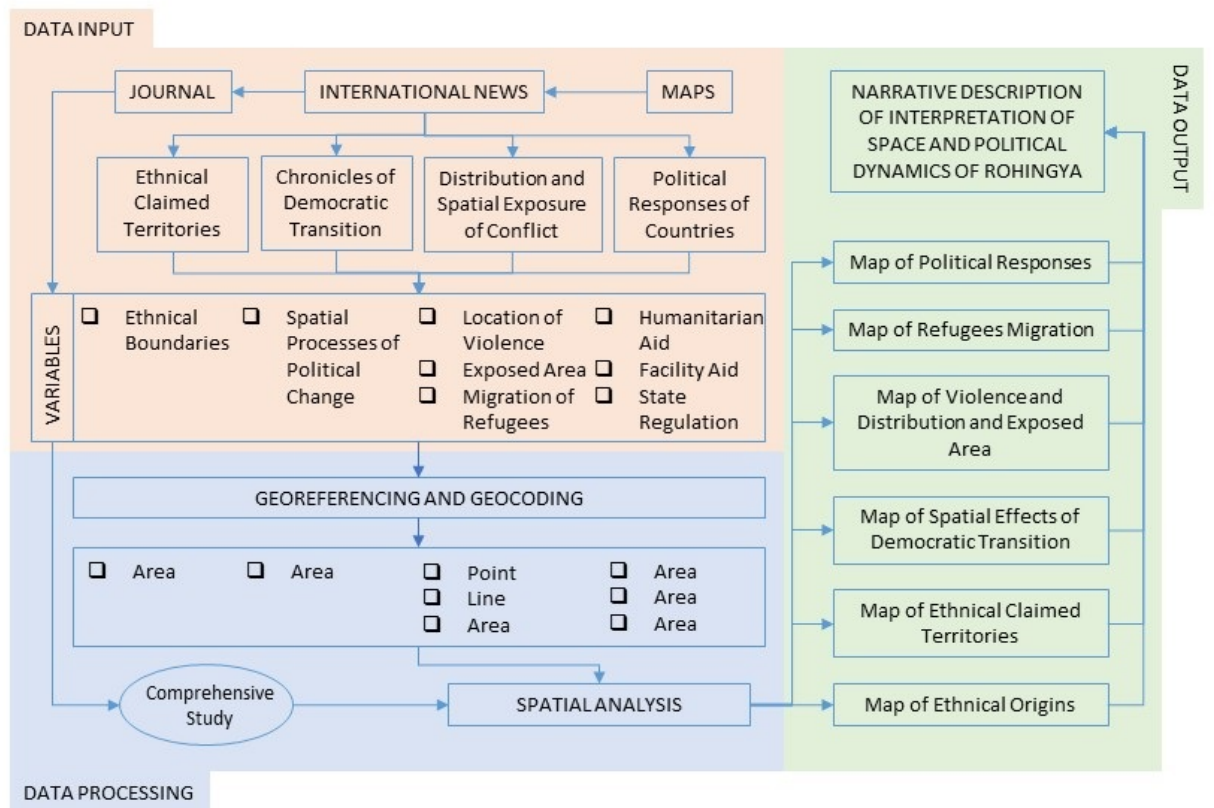

Fig. 2. Workflow of Research.

The diagram above shows the variables based on the major themes. After data collected from the sources of literature such as journals, international news, and maps, geocoding carried out to get the spatial features of the qualitative information into shape of point, line, and area. Geocoding is a set of transforming process of location attribute such as coordinates, address, or place's name into a projected location on surface of earth [14]. The maps were produced using ArcGIS 10.6.1. At the end of data processing, six maps of political phenomena will be obtained which be overlaid each other to get the interpretation of space and political dynamics of Rohingya.

\section{Results and Discussion}

\subsection{The Cultural Roots: Religious Communities and Dynastic Realm}

Ethnic as a single part of the nation, became the pros and cons of the times. The origin aspect, particularly in historical views, often biased to the real fact. The results of literature study reveal there were about five cultural roots in the Myanmar region that came to the land from varies, mainly from plains of China (Yunnan) and India. In the 10th Century, the Arakan region was an Indian land with a population similar to Bengal before the Mongolian and Tibeto-Burmans came to the property [15]. Ironically, even though the Arakanese Buddhists in Rakhine state were descendants of Arian Maghada 
from Bihar (India) and migrated around 8th century, they were identified as inhabitants among the stock of Mongolian [15]. The specific chronologies of upheaval were stated by Yunus (1994) as follow:

"In 1430 - 1638, all rulers of Arakan were descendants of Muslim King Solaiman Shah before he reinstated to the throne by Bengal King Sultan Jalaluddin Mohammad Shah. In 1430 - 1530, Arakan had an honorable relation to Bengal as feudatory to Bengal. Its boundary never extended beyond what was during the conquest of Arakan by Bengal Sultan. With the change of hands in power in Bengal in 1538, the Arakanese King Zabuk Shah occupied part of Southeastern Bengal including Chittagong for the first time in 1540. Oppositely, it lapsed back again to Bengal Sultans. For almost a century, from 1582 - 1666, Chittagong remained under the affective rule of the Arakanese" [15].

The following map reveals the ethnical origins in Myanmar States.
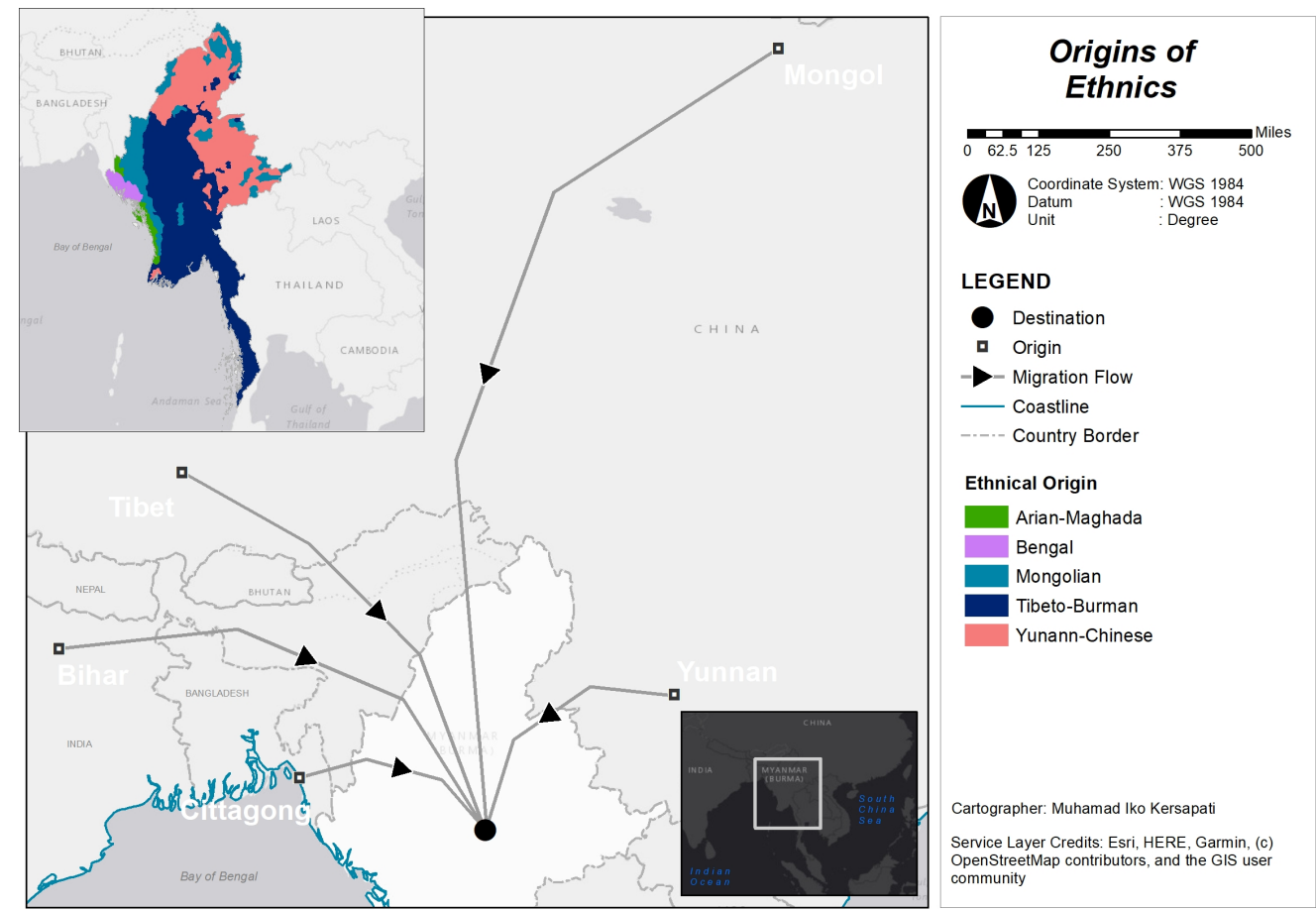

Fig. 3. Ethnical Origins in Myanmar States.

Proving the claims that circulating in society, was such a difficult thing to do. Nowadays, scholars and historians are trying to examine the claims by looking for the authentic facts to reveal the truth. The first subject of the application was related to the existence of Arakan's Mrauk U Dynasty. Rohingya people claim that they had lived in Rakhine State for centuries before Islam arrived in the region at the end of the 8th Century and believed that the famous Mrauk U Dynasty was a Muslim one. On the other 
hand, Rakhine and Bamar people claimed that the Mrauk U Dynasty was Buddhist, and Islam had only a small emersion in the state. Those claims have caused a high tension among the scholars because the requests from both parties contained the elements of truth.

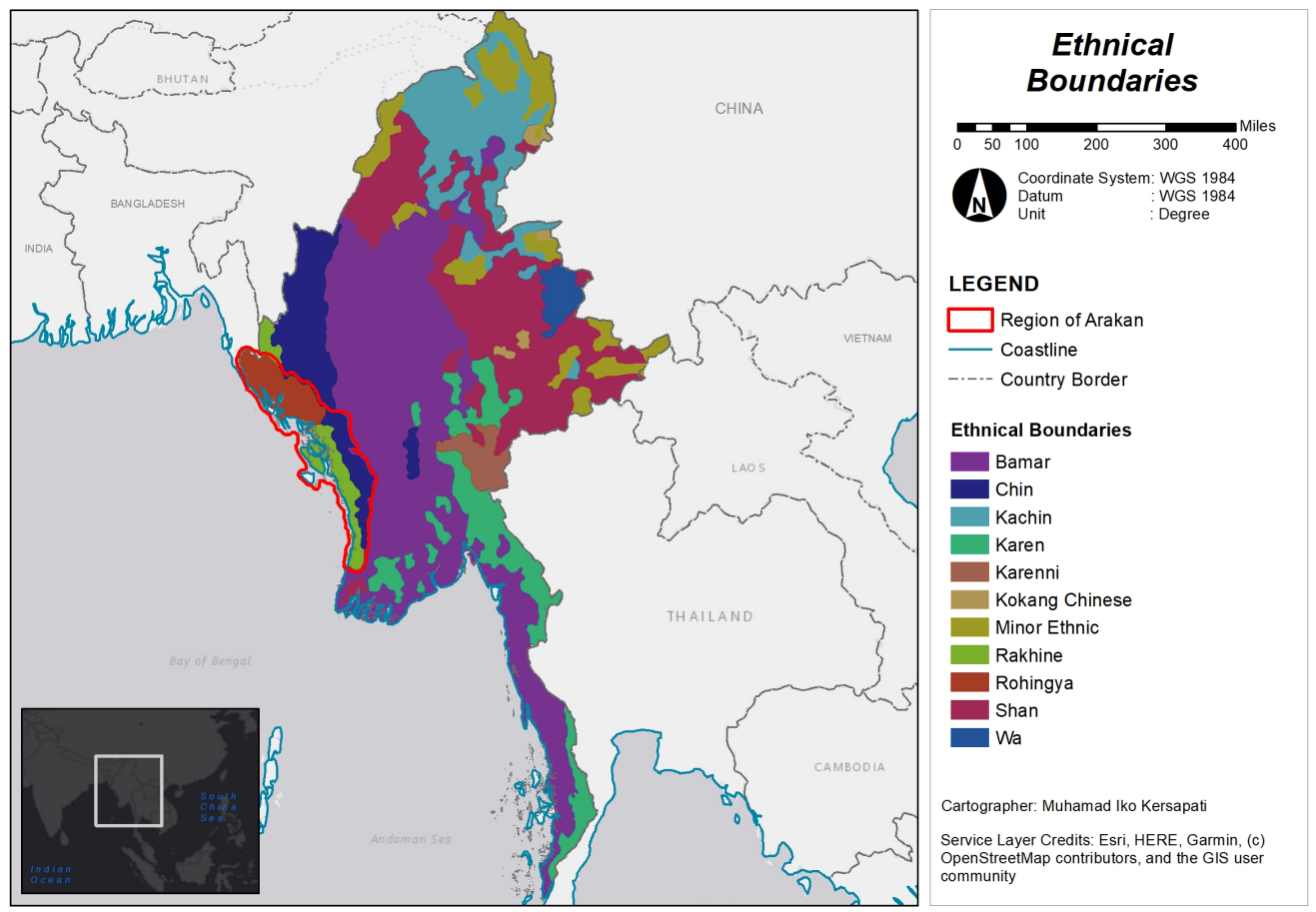

Fig. 4. Ethnical Boundaries in Myanmar States.

According to Frank Viviano, the ancestors of Rohingya families played crucial roles in Rakhine's cultural life. The documentation conducted by National Geographic revealed that Buddhist monarchs applied a unique cosmopolitan situation where merchants and intellectuals from different religious backgrounds were welcomed, particularly during the golden age of Arakan (Rakhine). King Min Saw Mon Narameikhla (also known as Sulaiman Shah), who established the dynasty, tended to side with his Muslim allies on the Indian Ocean rather than to hostile Buddhist principalities to the east. Rohingya historian Mohammad Yunus stated there were archeologists have been discovered several authentic proofs.

The discoveries such as: minted coins with trilingual inscriptions, in Arakanese, Bengali, and Arabic, bearing the Islamic profession of faith: "There is no God but Allah, and Muhammad is His Prophet.", and magnificent religious places of worship covering Santikan Mosque and Shitthaung Temple which were built in the same complex. On the contrary, Burmese government supporters believed that Arakanese were Buddhist even though they owned Muslim names and inscribed KalemaMuslim confession of faith was found on their coins. The scholars argued that the kings who adopted the Muslim names were actually Buddhist and only attempted to regain Arakan by gaining trust and help from Bengali Sultans. 
The map above shows the ethnical boundaries and distributions in Myanmar States. The census revealed, there are eight recognized ethnics, exclude Rohingya. Census could be very risky because it tended to rely on public perception upon sensitive elements such as ethnicity. When the census did not cover some of the groups from a specific society, it would cause complicated problems. For instance, the Burmese Government did not count Rohingya during the 2014 National Census because national perception described Rohingya people as illegal immigrants from Bangladesh. This phenomenon has triggered international society and international organizations such as United Nation and ASEAN to declare their disagreement towards the action. The U.N. agency said that went against earlier promises.

"In its agreement with the United Nations ... the government made a commitment to conduct the exercise in accordance with international census standards and human rights principles," it said in a statement. "It explicitly agreed with the condition that each person would be able to declare what ethnicity they belong to." [16].

Based on a publication of Anadolu Agency, the unofficial number of Muslims estimated to be at $4.61 \%$ of the total number of inhabitants in 2014 . However, analysts stated that this number might be higher in realistic insight that can be known from last census in 1983, where the number of Muslim populations was estimated around $10 \%$. Tin Maung Than, secretary-general of the country's official Muslim body, the Islamic Religious Affairs Council Myanmar, told:

"The procedure for a Muslim to get a National Registration Card is very complicated and confused, so many people (Muslims) fill them in as 'Buddhist' to make it easier (to get a card). These people then list them as Buddhists in the census too."

On the other hand, pro-government scholars mostly believed that Rohingya people were the outsiders who migrated during the British colonial era. The term "Rohingya" itself was firstly introduced by erudite Bengali inhabitants in 1950s, but this term could not be traced in any archive of historical pathways [17]. When the British occupied the state, the Bengali people from adjacent areas were brought out to work as farmers resulted in mass migration and the opening of settlements. As the British East India Company extended the administration of Bengal to Arakan, the boundaries between the two countries did not seem visible, and there were no such policies ruling the emigration. A colonial record stated:

"Bengalis are a frugal race, who can pay without difficulty a tax that would press very heavily on the Arakanese....(They are)not addicted like the Arakanese to gambling, and opium smoking, and their competition is gradually ousting the Arakanese (Report of the Settlement Operation in the Akyab District 1887-1888: 21)”.

\subsection{Political Dynamic: Democratic Transition}

The economic destruction of Myanmar caused by various economic sanctions had a massive impact on its people. The 2007 demonstration was the culmination of anger of multiple parties (civil society, including religious leaders), a turning table for the democratic transition. Since then, Myanmar was increasingly under pressure from the international community upholding human rights and democracy. This situation could be proved by the US initiative in pushing the United Nations to impose sanctions on Myanmar in the name of global stability. It was also thought to be the reason for the redeployment of the capital from Yangon to Naypyidaw [18]. 


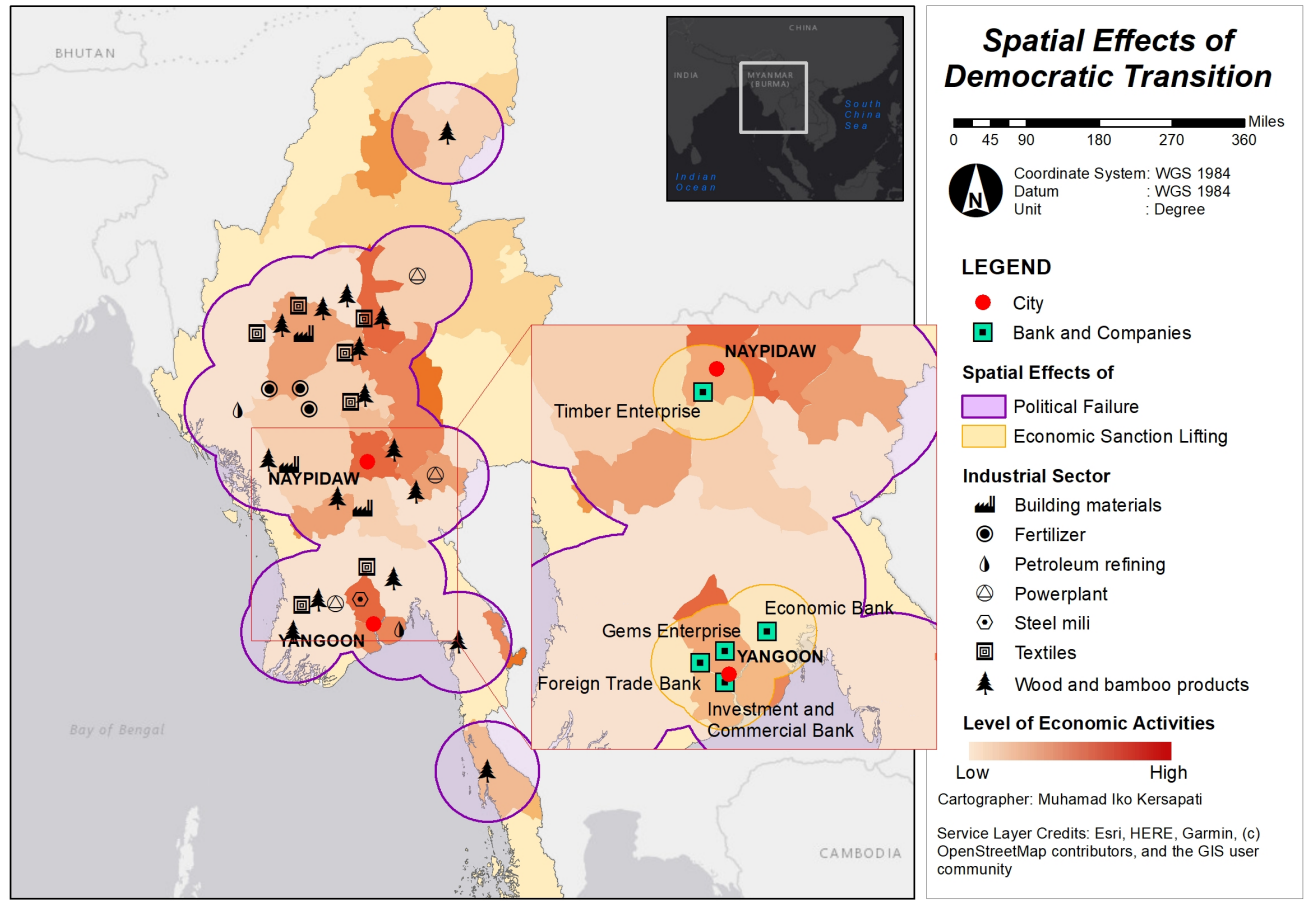

Fig. 5. Spatial Effects of Democratic Transition.

The failure of the regime led to a lack of investment, particularly in the industrial sector. Investors tended to have a particular advantage in conflict-affected countries because those countries face enormous challenges in attracting investment [19]. Based on these facts, authors overlaid maps of economic activity level and industrial spots in Myanmar. The economic activity level implicitly revealed the effect of economic sanctions on economic development through the space of activity. According to "GeoCurrents", the economic activity level map could be produced by using the strength and distribution of nighttime lights [20]. The following map shows the effect of economic sanctions on the industrial sector distributed to the high level of economic activity area, particularly in the center of Myanmar.

The military junta could not deny that Myanmar's domestic economy was still heavily dependent on foreign aid funds. Considering the fact above, they have finally accepted global developments, particularly democracy, as the prominent elements in transitioning Myanmar as an emerging modern country. To rebrand the image of the authoritarian regime, the presidential election was conducted in 2010, where the military junta, the State Peace and Development Council (SPDC), officially handed over its power to President Thein Sein on 30 March 2011.

Under the leadership of Thein Sein, there were efforts designed to change the international perceptions of the national government. His policies indicated that there was the willingness to regrow the democracy in Myanmar by freeing prisoners and exiling activists return to Myanmar and providing the freedom of speech, particularly for the news stations. Journalists have criticized the authoritarian regime in the past. Besides, Thein Sein also allowed the National League for Democracy (NLD) to 
participate in the 2012 election in which Suu Kyi managed to get a parliamentary seat in the government.

His efforts in building democracy have received positive responses from the international community. At least, there were two great achievements during the era would like to be mentioned. The first accomplishment was the inauguration of Myanmar as the chair of ASEAN for the first time in 2014. The transition from the authoritarian to a democratic regime had a considerable effect on Myanmar's position in a global system. Marty Natalegawa, former Indonesia's Minister of Foreign Affairs, said that the election of Myanmar as the new ASEAN chairman was universally approved by all ASEAN members. Besides that, fellow ASEAN members also showed their commitments to fostering the democratization process in Myanmar.

The second achievement was the ability of the new regime to lift the economic sanctions. Several US economic sanctions were covering the normalization of financial transactions, travel tours, and the removal of companies from the blacklist successfully lifted. According to the U.S. Department of the Treasury's Office of Foreign Assets Control (OFAC), in early 2016, there were 7 banks and companies removed from the US blacklist, such as Myanmar Economic Bank, Myanmar Foreign Trade Bank, Myanmar Investment and Commercial Bank, Co-operative Export and Import Enterprise, Myanmar Gem Enterprise, Myanmar Pearl Enterprise, and Myanmar Timber Enterprise.

According to the map, the banks and companies removed from the blacklist were located on the high level of economic activity where Yangon and Naypyidaw (New Capital City of Myanmar) were found in the region. It showed that the democratic transition that occurred in Myanmar has produced the spatial hegemony in the area of the high level of economic activity. Many democracy countries were presenting their own appreciation to the progress. The United States is currently normalizing diplomatic relations with Myanmar. On the other hand, Japan was providing scholarships for Myanmar citizens to study democracy in Japan. Also, Japan has spent 700,000 USD to support freedom, particularly in balanced broadcasting, reducing information gaps in Myanmar's society.

\subsection{Geography of Conflict: Distribution and Spatial Exposure}

According to the International Crisis Group (ICG) in the Department of Parliamentary Services Australia (2013), there were two episodes of the violence to the Rohingya in June and October 2012 [21]. ICG states:

"Dozens were killed, hundreds of houses burned, and 75,000 mostly Rohingya displaced by subsequent intercommunal violence in northern Rakhine State and around the Provincial Capital of Sittwe." [21].

Meanwhile, the next assault took place on 21 October. The locations of violence were scattered in the north and west towns of Rakhine State such as Kyaukpyu, Kyauktaw, Minbya, Mrauk-U, Myebon, Pauktaw, Ramree, and Rathedaung. More organized assault directed towards Muslim generally, not only Rohingya, and could be escalated. In addition, Kaman community (another Muslim ethnic in Myanmar) also became a target. This situation showed that the conflict became more of an ethnical problem but religious. 

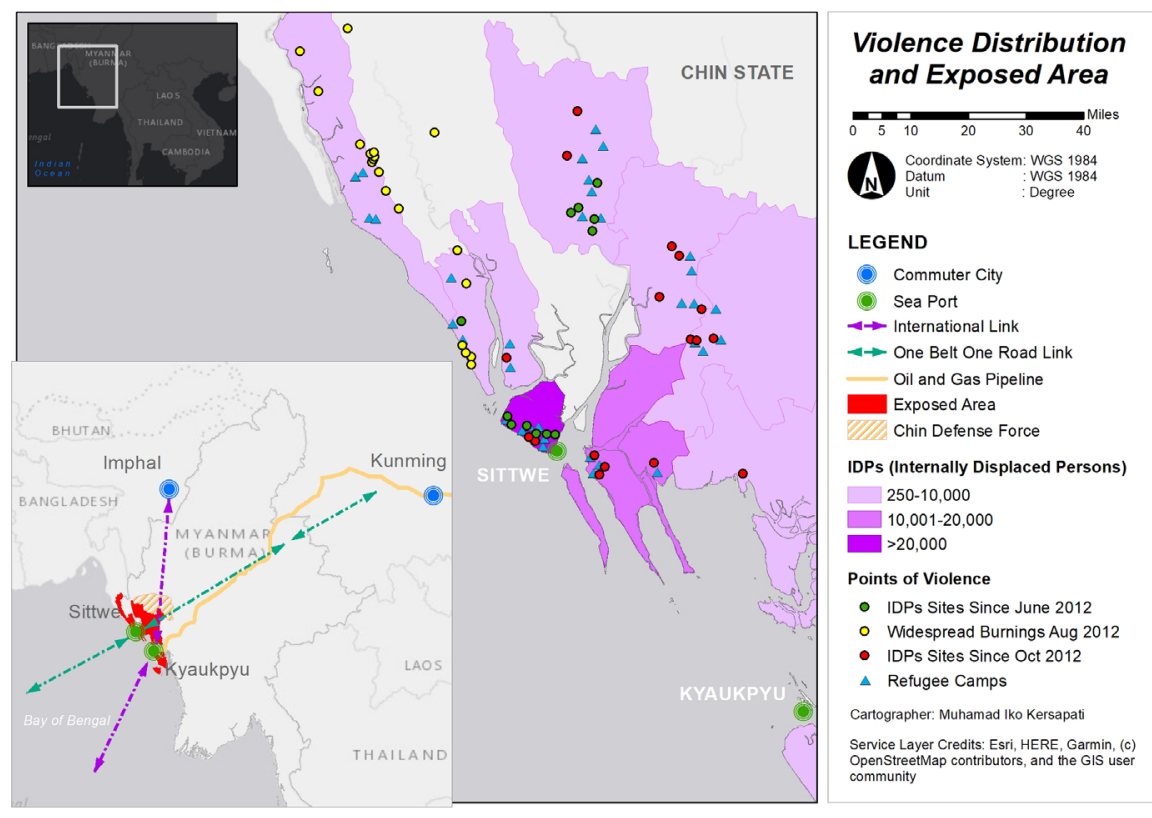

Fig. 6. Violence Distribution and Exposed Area.

Satellite imagery data from Human Rights Watch in August - September 2012 also showed widespread burnings in some areas on northern, Maungdaw and Taungpyoletwea. The map above shows the distribution of IDPs (Internally Displaced Persons) sites in June and October simultaneously by widespread burnings in August - September 2012.

The highest IDPs (Internally Displaced Persons) - People forced to get out of their home but within the country's borders - shown in Sittwe as the capital city, i.e., more than 20,000 people were evicted. The results of the investigation indicate another factor in the regional aspect. The Rohingya eviction case from Rakhine State was not only a matter of religion and ethnic, but also of political economy.

The international news website "The Conversation" mentioned that regional prize and land grabbing became secondary factors of conflict in Rakhine State [22]. Rakhine State as the broader coastal plain to India and China, gave oil and gas stockpile as sender from the Middle East. China National Petroleum Company (CNPC) took this opportunity by making a transnational parallel pipeline from Kyaukpyu Sea Port and Sittwe Capital City of Rakhine to Kunming (China), as shown in the map above.

Land grabbing often started in vulnerable land and could be identified as geopolitics maneuvering. This treatment also became a real example of broader eviction to the minorities [22]. As stated by "The Conversation":

"When a group is marginalized and oppressed it is difficult to reduce their vulnerability and protect their rights, including their property. In the case of the Rohingya, their ability to protect their homes was decimated through the revocation of their Burmese citizenship." 
The conflict of Rohingya - Rakhine in the State became things beyond the religion and ethnical issue. The production of space of the war-affected serious impact, particularly in accessibility and connectivity in the region. As shown by figure 6, Sittwe - the Capital City of Rakhine State was an international link to the Imphal (India) and One Belt One Road Link to the Kunming (China). This situation gave immediate and long-term economic, political, and security implications for the rest of the region [23]. As stated by an international news website "Asia Times":

"The Nikkei Asian Review recently reported that widespread condemnation of Myanmar's military crackdown on Rohingya Muslims has raised concerns among some investors about the re-imposition of sanctions that could hinder future foreign investment."

The dynamic of conflict that occurred in Rakhine State caused most of the Rohingya people to escape to the country and the closest region of which were Bangladesh, India, Thailand, Malaysia, and Indonesia. The following map shows the number of refugees in the neighboring countries of Myanmar and the migration flow of Rohingya refugees. The map shows that Bangladesh and India were the countries with the most significant number of refugees, about more than 40,000 people. This number was closely related to the geographical element of Myanmar, which was very close to India and Bangladesh, the sense of belonging of the Rohingya to their ancestral land.

Most of the Rohingya refugees were scattered to the southeast (Thailand, Malaysia, and Indonesia) and north to Bangladesh. They entered the Region of Bangladesh from Naf River to several areas, such as Nayapara, Thaingkali, and Cox's Bazaar. The highest number of refugees is in Cox's Bazaar area (about more than 100 people in the refugee camps), this was encouraged by its economic development as a tourism destination. Chronologically, the distribution of the refugees consisted of several parts. According to the Humanitarian Information Unit (HIU) U.S. Department of State, there were five phases of the migration and occurred in January - February 2013. The detail of movement of the refugees shown in figure 7.

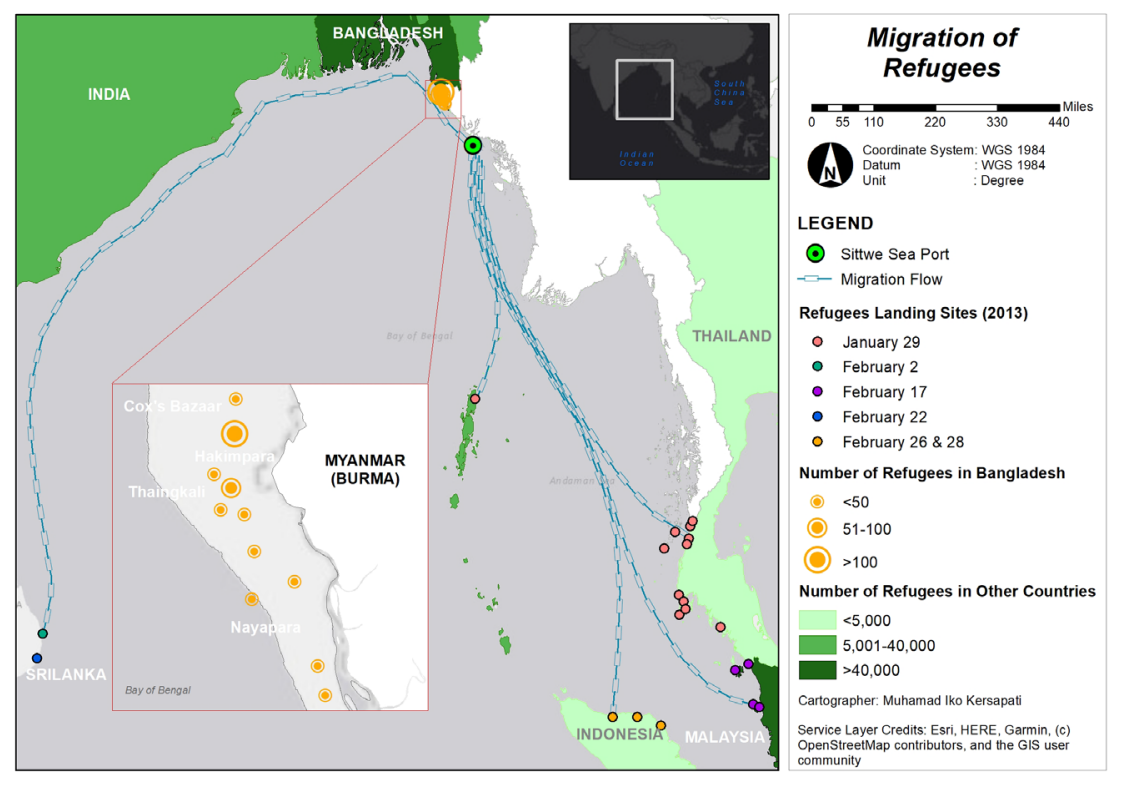

Fig. 7. Refugees Migration. 
Based on the map, chronology of refugees' escape divided into six phases in 2013. The first phase occurred on January 29th. 108 Rohingya (including 26 women and 13 children) rescued off the coast of Phangnga, Thailand. On February 2nd, 138 people were rescued by Sri Lanka's Navy from Bangladesh and Myanmar. On February 17, 140 Rohingya people landed at Teluk Bahang National Park, Malaysia. They escaped to the forest. On February 22nd, a boat was rescued on 250 miles off the east coast of Sri Lanka. 97 people died and 32 survived. The last part, in February 26 and 28th, 121 people recued on board (including 23 children) by anglers in Aceh, Indonesia.

As time went on, the Rohingya refugees experienced many bitter crises in terms of food, clothing, shelter. They also suffered from human rights disabilities granted by Myanmar's own country and Bangladesh. Until now, many international news reports about protests from Rohingya refugees against Myanmar and Bangladesh. Rohingya refugees live in crowded and cramped spaces and continue to live in conditions such as emergencies, which increase the threat of potential outbreaks of infectious diseases.

While fleeing to the Cox's Bazar area which is a part of Bangladesh, the crisis experienced by Rohingya refugees included health problems such as respiratory infections, diarrhea and skin diseases, increasing number of patients from August 2017 to March 2019, sanitation \& water clean, outside activities, and health facility issues [24]. A large scale of aid is needed to save the lives of refugees and to manage conflict. With urgent needs in food security, WASH, shelter, location management, health, and nutrition in settlements and host communities. The existing Rohingya population already has immediate needs across sectors. A comprehensive and sensitive response to conflict is needed to take into account Rohingya refugees at Cox's Bazar [25].

The Cox'z Bazar area, with a population of 2,290,000, the majority are Bengali Muslims, is the poorest and most vulnerable district in Bangladesh. On average, $33 \%$ and $17 \%$ live below the poverty line and the last most impoverished line. The increasing refugee population further aggravated the situation, and would adversely affect food security and nutritional status, and have an impact on the local economy. Increasing population and further density will likely affect primary roads and existing market infrastructure, resulting in the need to build services, with congestion already a major problem limiting access and mobility around significant locations [25].

Bangladesh said it would harden its attitude towards the Rohingya refugees currently in the country. As reported in bbc.com news (2019), Bangladesh's Foreign Minister Abdul Momen said that Bangladesh could not continue to bear the economic burden. Still, he did not say exactly how the policy would change. Over 740,000 inhabitants of Rohingya migrated to Bangladesh camps in August 2017 after the event of Muslim minority attack by military [26].

Then reported from theguardian.com (2019), Rohingya refugees refuse to be returned to Myanmar without guarantee of Human Rights. In an interview conducted by the guardian reporter who interviewed one part of the Rohingya, it was said that they would not return until their main demands were met, Rakhine was still hostile and insecure for them. They wanted a guarantee of citizenship first, and the Rakhine people must call them Rohingya, then they can leave. They would not leave if they do not get their rights, such guarantees from the Myanmar government that our citizenship rights will be returned [27].

In Myanmar, entire villages burned down, families separated and killed, and gang groups raped women and girls. Mostly, people who ran away experience severe trauma after witnessing unspeakable atrocities. Rohingya remain in a hazardous situation. The root cause of their suffering in Myanmar has not been overcome, and their future is uncertain. Refugees had access to basics, such as food and health care. However, they were still very vulnerable, lived in very challenging conditions, are exposed to monsoon elements, and depend on assistance [28]. 


\subsection{Political Responses of Neighboring Countries}

In this section, the authors will discuss the responses of neighboring countries such as Bangladesh, Thailand, Malaysia, and Indonesia. There were contrast reactions between the prominent actors toward Rohingya. Based on the investigation, Bangladesh's minister of finance, A.M.A. Muhith, has shown his disagreement towards accepting the Rohingya based on the "New York Times" interview. He said:

"In a sense, Myanmar has declared war by sending the Rohingya to Bangladesh. They are trying to jeopardize our economy by sending people from their country." [29].

On the other hand, Bangladesh's Prime Minister Sheikh Hasina tended to welcome Rohingya in a very positive way. There were at least two main points that Bangladesh should do in minimizing the issue. First, the problem should be solved in Myanmar since it was their domestic issue. She believed that Bangladesh and the Rohingya needed the U.S. and India to use their substantial authorities to pressure Myanmar to stop driving the Rohingya out [30]. Second, she has promised the Rohingya for providing a more presentable camp compared to the existing two camps in Cox's Bazaar. The government of Bangladesh has crafted a plan of constructing a new settlement in Thegar Char (an island in the northern Bay of Bengal) where the infrastructure such as housing, schools, hospitals, health centers, mosques, and roads will have been provided by the government [31].

Thailand's government, in response to the human rights violation in Myanmar, could not guarantee to provide a long-term shelter for Rohingya to live since Thailand did not sign and ratify the 1951 UN Status of Refugee convention. In 2008, Thailand implemented the pushing out policy in response to the refugee crisis. Thailand's government could not assist Rohingya in working in Thailand. In contrast, as one of the ASEAN members, Thailand has also committed to achieving world peace. In spite of Thailand did not ratify the 1951 UN Status of Refugees Convention [32], General Prayut Chan-Ocha as the Thailand Prime Minister still expressed its contribution to protect Rohingya by providing the humanitarian aid as well as a temporary shelter. Cooperating with Thailand's Defense Ministry and Security, Thailand's government was ready to help the Rohingya's a temporary shelter.

Meanwhile, Malaysian Prime Minister, Datuk Seri Najib Razak provided humanitarian aid to Rohingya refugee in Bangladesh about 10 million ringgits (\$2.25 million) through an integrated IM4U as voluntary organization joined with Malaysian Aviation Industry such as Malaysia Airlines in terms of ensuring the humanitarian aid has safely arrived to destination [33]. Malaysia has firmly committed to granting humanitarian to those who needed it. Therefore, the assistance for the Rohingya community will have been delivered to Chittagong, Bangladesh, via Mabkargo's AA30. Thus, to fulfill the necessary supplies, IM4U would distribute the humanitarian aid at Rohingya refugee camps in Cox's Bazaar District of Bangladesh. Otherwise, in responding to the issue, Malaysia was nor experienced in managing or maintaining the refugee movement [34]. This response has been proven since the Malaysian government showed its commitment to offering refugee protection in the country [34]. The refugee integration policy managed refugee settlement and land distribution towards refugees. The policy of integration might not succeed without the acceptance of the Sultans and the leaders of the Malaysian Federal Government [34].

The efforts to reduce the escalation in Myanmar by both Myanmar's government and other countries were still ongoing to Indonesia. It has been the role model in promoting peace talks and dialogue on human rights violations in Rakhine State. Thus, on August 31st, 2017, Indonesia has officially launched a humanitarian alliance named Humanitarian Assistance for Sustainable Community (HASCO). The humanitarian program aimed to support Rohingya on capacity building, experts, livelihood, rehabilitation, and food security [35]. Besides that, in the education sector, Indonesia has donated 1 million USD for building of schools in 2014 and 2017 [35]. These programs 
showed Indonesia's most active commitment in supporting Rohingya. Indonesia also delivered Myanmar's government should immediately solve the ethnical conflict in a constructive way based on the value of democracy [36]. The following map reveals the responses pro and contra, or even both.

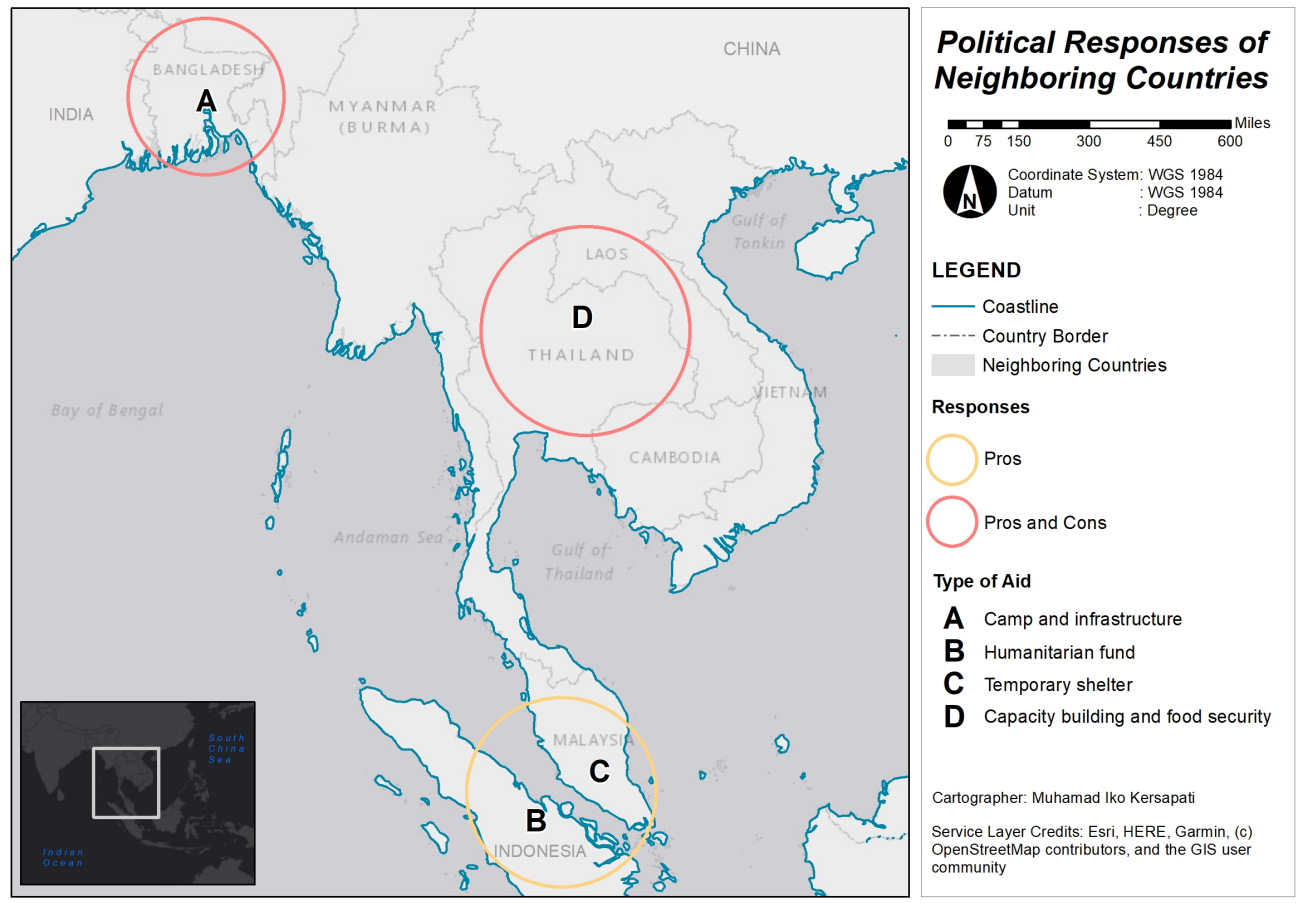

Fig. 8. Political Responses of Neighboring Countries.

\section{Conclusion}

From the results, concluded that the conflict of Rohingya had some impacts on the space of activity such as religious and ethnical life, politics and economics, defense and security, etc. Rohingya had difficulty obtaining territorial sovereignty as part of Myanmar. Several sources stated that the conflict was related to religious background. Nevertheless, it has been very much developed very complex, not just a matter of religion-ethnicity but also political economy. The economic sanction given by the US to Myanmar had an impact on economic activity, particularly the weakening of investment value in the industry as a sector supporting the economy of the country.

The democratic transition that occurred in Myanmar provided an opportunity for foreign economic power such as China to build an oil and gas pipeline from Kyaukpyu to Kunming, China. This condition led to land grabbing and marginalization of Rohingya as the inhabitant. The satellite imagery revealed that the highest IDPs (Internally Displaced Persons) i.e., more than 20,000 people, are evicted. They flee to the southeast (Thailand, Malaysia, and Indonesia) and north to Bangladesh. Connectivity problem in Sittwe - the Capital City of Rakhine State, which is an international link to the Imphal and One Road Link to the Kunming, gave immediate and long-term economic, political, and security implications for the rest of the region.

In political responses to the conflict, there were contrast reactions between the prominent actors toward Rohingya. Indonesia and Malaysia gave pro response. Indonesia has officially launched a 
humanitarian alliance named Humanitarian Assistance for Sustainable Community (HASCO). Meanwhile, Malaysian Prime Minister, Datuk Seri Najib Razak provided humanitarian aid to Rohingya refugee in Bangladesh about 10 million ringgits ( $\$ 2.25$ million) through an integrated IM4U as voluntary organization joined with Malaysian Aviation Industry such as Malaysia Airlines in terms of ensuring the humanitarian aid was safely arrived to destination.

\section{References}

[1] Antara News, "antaranews.com," 31 August 2017. [Online]. Available: https://en.antaranews.com/news/112453/indonesia-encourages-myanmar-government-to-restoresecurity-in-rakhine.

[2] Independent, "Rohingya Muslims Fleeing Genocide are a 'security threat', Syria's Grand Mufti Claims," 3 October 2017. [Online]. Available: http://www.independent.co.uk/news/world/middleeast/rohingya-muslims-syria-grand-mufti-security-threat-burma-genocide-sheikh-ahmad-badreddinhassoun-a7980601.html.

[3] Ministry of Foreign Affairs Republic of Indonesia, "Indonesian Foreign Minister Headed to Myanmar to Meet Myanmar State Counselor Daw Aung San Suu Kyi," 3 September 2017. [Online]. Available: $\quad$ https://www.kemlu.go.id/en/berita/Pages/Indonesian-Foreign-Minister-Headed-toMyanmar-to-Meet-Myanmar-State-Counselor-Daw-Aung-San-Suu-Kyi.aspx.

[4] Ministry of Foreign Affairs Republic of Indonesia, "Indonesian Foreign Minister: Deescalation of Tensions in Rakhine State is a Priority," 4 September 2017. [Online]. Available: https://www.kemlu.go.id/en/berita/berita-perwakilan/Pages/De-escalation-of-Tensions-in-RakhineState-is-a-Priority.aspx.

[5] K. T. W. Cho and G. J. Gimpel, "Geographic Information System and the Spatial Dimensions of American Politics," Annual Review of Political Science, p. 19, 2012.

[6] B. Anderson, Imagined Communities: Reflection on the Origin and Spread of Nationalism, London: Verso, 2006.

[7] R. Muir, "Modern Political Geography," Wiley, 1975.

[8] T. Winichakul, "Siam Mapped A History of the Geo-Body of a Nation," University of Hawai'i Press, 1994.

[9] United Nations Declaration of Human Rights, "Part I the Concept of Human Rights," 1948. [Online]. Available: http://www.humanrights.is/en/human-rights-education-project/human-rightsconcepts-ideas-and-fora/part-i-the-concept-of-human-rights.

[10] J. C. Montero, "Human Rights, International Human Rights, and Sovereign Political Authority: a Draft Model For Understanding Contemporary Human Rights," Ethics \& Global Politics, pp. 143$162,2014$.

[11] Y. Nishikawa, "The reality of protecting the Rohingya: An inherent limitation of the responsibility to protect," Asian Security, pp. 1-17, 2018.

[12] government technology, "Putting Violence on the Map," 2 June 2006. [Online]. Available: https://www.govtech.com/public-safety/Putting-Violence-on-the-Map.html.

[13] K. Holloway, "Dignity and Displaced Rohingya in Bangladesh," Overseas Development Institute, London, 2018.

[14] ESRI, "What is Geocoding?" 2017. [Online]. Available: http://pro.arcgis.com/en/proapp/help/data/geocoding/what-is-geocoding-.htm.

[15] M. Yunus, "A History of Arakan (Past \& Present)," p. 38, 1994

[16] K. M. Win, "UN concerned Rohingya excluded from Myanmar census," 2 April 2014. [Online]. Available: http://www.thejakartapost.com/news/2014/04/02/un-concerned-rohingyaexcluded-myanmar-census.html.

[17] A. Chan, "The Development of a Muslim Enclave in Arakan (Rakhine) State of Burma (Myanmar) in SOAS Bulletin of Burma Research, Vol. 3, No. 2," SOAS Bulletin, p. 397, 2005. 
[18] A. Millington, "Inside Burma's Ghost Town Capital City, which is 4 Times the Size of London with a Fraction of the Population," 23 June 2017. [Online]. Available: http://www.independent.co.uk/travel/inside-burma-s-ghost-town-capital-city-which-is-4-times-thesize-of-london-with-a-fraction-of-the-a7805081.html.

[19] EIRIS Conflict Risk Network, "Investment Watch: Burma/Myanmar," EIRIS Briefing Paper, p. 4, May 2014.

[20] M. W. Lewis, "Mapping Nighttime Light and Economic Development in Burma," Geocurrents, p. $4,2014$.

[21] Department of Parliamentary Services, Australia, "Myanmar: Sectarian Violence in RakhineIssues, Humanitarian Consequences, and Regional Responses," Parliamentary Library, p. 38, 2013.

[22] The Conversation, "Religion is not the only Reason Rohingya are being Forced Out of Myanmar," 12 September 2017. [Online]. Available: http://theconversation.com/religion-is-not-theonly-reason-rohingyas-are-being-forced-out-of-myanmar-83726.

[23] Asia Times, "Asean Dangerously Silent on Rohingya Crisis," 18 May 2017. [Online]. Available: http://www.atimes.com/article/asean-dangerously-silent-rohingya-crisis/.

[24] Medecins Sans Frontieres, "www.msf.org," 14 May 2019. [Online]. Available: https://www.msf.org/bangladesh-rohingya-crisis-update-may-2019.

[25] OCHA, "Rohingya Refugee Crisis," Humanitarian Response Plan, pp. 1-52, 2017.

[26] BBC News, "Bangladesh 'to be tougher' on Rohingya refugees," 24 August 2019. [Online]. Available: https://www.bbc.com/news/world-asia-49460386.

[27] H. E. Petersen and S. A. Rahman, "Rohingya refugees refuse to return to Myanmar without rights guarantee," 21 August $2019 . \quad$ [Online]. Available: https:/www.theguardian.com/world/2019/aug/21/not-without-our-rights-rohingya-refugees-refuse-toreturn-to-myanmar.

[28] OCHA, "www.unocha.org," 29 August 2018. [Online]. Available: https://www.unocha.org/rohingya-refugee-crisis.

[29] The New York Times, "How the Rohingya Crisis is Changing Bangladesh," 6 October 2017. [Online]. Available: https://www.nytimes.com/2017/10/06/opinion/rohingya-bangladeshmyanmar.html.

[30] The Diplomat, "Once Persecuted Bangladesh Proud to Help Rohingyas," 25 September 2017. [Online]. Available: https://thediplomat.com/2017/09/once-persecuted-bangladesh-proud-to-helprohingyas/.

[31] The Diplomat, "Bangladesh Extending Aid, Upgrading Facilities to Displaced Rohingya," 7 April 2017. [Online]. Available: https://thediplomat.com/2017/04/bangladesh-extending-aidupgraded-facilities-to-displaced-rohingya/.

[32] ASEAN Today, "The Thai Government Will Shelter Rohingya: Another Empty Gesture for ASEAN's Forgotten Victims," 11 September 2017. [Online]. Available: https://www.aseantoday.com/2017/09/the-thai-government-will-shelter-rohingya-another-emptygesture-for-aseans-forgotten-victims/.

[33] New Straits Times, "Malaysia to Launch Humanitarian Mission to Aid Rohingya Refugees via

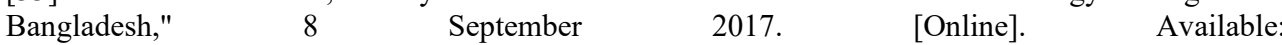
https:/www.nst.com.my/news/nation/2017/09/277683/malaysia-launch-humanitarian-mission-aidrohingya-refugees-bangladesh.

[34] A. Idris, "Malaysia and Force Migration," Intellectual Discourse Vol. 20, No. 1, IIUM Press, p. $38,2012$.

[35] Dakta.com, "Ministry of Foreign Affairs of Republic Indonesia and Indonesian Humanitarian Allience Has Launched HASCO for Rohingya," 8 August 2017. [Online]. Available: http://www.dakta.com/news/10790/kemlu-dan-akim-luncurkan-program-hasco-untuk-rohingya.

[36] Liputan 6, "Indonesian Minister Has Officially Established Non-Profit," 31 August 2017. [Online]. Available: http:/global.liputan6.com/read/3078175/menlu-ri-resmikan-lsm-dan-bantuankemanusiaan-untuk-rohingya. 